\title{
Yet Another Lame Duck Survives
}

THE British government's conversion to the prirciple that an industry in trouble should have support from public funds is now almost complete, but the Conservative government seems to be no clearer than its Labour predecessor about the reasons for its generosity. Early this week, $\mathrm{Mr}$ Christopher Chataway, the Minister for Industry, announced that the government is to invest $£ 4.9$ million in a new company formed from the Norton-Villiers Division of Manganese Bronze Holdings Limited and Birmingham Small Arms Limited with the objective of manufacturing motor cycles. The need for this investment has come about because the Birmingham Small Arms company, which has long since exchanged its manufacture of rifles and other military weapons for the outwardly pacific but hardly less offensive trade of manufacturing motor cycles, has had two disastrous years in a row and has reached the point of collapse. The Norton-Villiers organization, by contrast, has been relatively successful in the past few years, recovering slowly but steadily from the collapse of its American market when, apparently to everybody's surprise, Japanese motor cycle manufacturers began selling motor cycles with large engines which were technically superior to those of their British competitors. What $\mathrm{Mr}$ Chataway said this week is that the government's investment in the new company is intended to secure an export market that could be worth $£ 30$ million a year in the decade ahead.

Several questions need urgently to be asked of the government. First, if the export of motor cycles is considered to be strategically necessary-and there is room for argument about that -might it not have been better that the public money now committed should have been invested in the successful company and not in its amalgamation with the unsuccessful company? No doubt the government is anxious to avoid the loss of jobs that would result from the complete collapse of BSA, given the several frights about the level of unemployment received last winter, but on this occasion it need not have worried. An investment in the successful company would surely have meant that the relevant parts of BSA, and the workers concerned, would have been snapped up. As things are, the shareholders, the management and the labour force of BSA will be protected from the knowledge that they have failed. And the government will have lost yet another chance of making good its persistent failure to recognize, in the recent history of public investment in British industry, that it is better to invest in successful enterprises than Mr John Davies's now proverbial lame ducks.

The second question, on which both the Labour and Conservative governments have been repeatedly caught out, is whether the new enterprise will be viable even with the government investment and the $£ 10$ million which it is hoped that the banks will now lend. For there is no secret behind the success of Japanese motor cycle manufacturers in the American market in the past few years. By the use of multi-cylinder engines, overhead camshafts and such devices as electric starting motors, they have been able to sell products which are in many ways superior to those of British manufacturers. In the years ahead, the technical competition is likely to be still fiercer. It cannot be long before Japanese manufacturers are marketing machines which use rotary engines. It is vitally important to know whether the new company now put together will be able to suport research and development on the scale necessary to make it competitive in the 1980s. If it cannot, the outcome could be yet another failure in the not too distant future.

Yet another question which the government must answer is whether investment in motor cycle manufacturing is strategically worthwhile. It is not, after all, as if Britain is starved of opportunities for industrial investment. Indeed, there are several other ways in which an export business in less marginal products than motor cycles might he built up. To be sure, the government is worried about employment, while its hands are to some extent tied by the inflexibility of the British labour force. People brought up to manufacture motor cycles seem slow to recognize that they can just as well help to manufacture other kinds of industrial products, not merely motor cars but vacuum cleaners, refrigerators and the like. That said, however, there is also an urgent need for a re-examination of the government's plans for industrial retraining. Is it not high time that more efficient machinery for converting people to technologically advanced work was implemented? It could easily turn out, on a narrow accounting basis, that Britain would get better value for the money the government is now proposing to invest in making motor cycles by using it, instead, for sensible training programmes. In the long run, however, the only sustainable objective is that there should be a programme for the development of British industry which will provide not merely a skilled and adaptable labour force but a coherent strategy for deciding what should be manufactured. There is nothing wrong with the mechanism which exists already by means of which commercial institutions decide whether or not to risk money in new enterprises. The government's intervention, in the BSA case as well as in the rescue of other lame ducks in recent months, has blunted this machinery.

\section{Princeton in Trouble}

The Institute of Advanced Study at Princeton is one of the most distinguished of all academic institutions in the western world. The tiny faculty of twenty-six has been able to exercise a profound influence on the development of scholarship, partly because of the quality of its members (including Einstein, von Neumann and Oppenheimer) and partly because of the historical accident that the institute functioned, in the 1930s, as a splendid 